\title{
ANALISIS TINGKAT KESEHATAN PT. BPR WELERI MAKMUR DENGAN METODE CAMEL PADA PERIODE 2015-2018
}

\author{
Nabila Saskia Noer Rizky*) \\ Winarni**) \\ *)nabilasaskianr23@gmail.com
}

\begin{abstract}
This study aims to assess and analyze the health level of PT. BPR Weleri Makmur if calculated using the CAMEL (Capital, Asset Quality, Management, Earning, and Liquidity) method in the 2015-2018 period based on Bank Indonesia Director's Decree No. 30/12 / KEP I DIR dated April 30, 1997. The component assessed is Capital (Capital) using CAR ratios, Asset Quality by using KAP ratios and PPAP ratios, Management using Management calculations using general management and risk management, earnings (earning) using the ROA ratio and the BOPO ratio, and Liquidity (Liquidity) using the Cash Ratio and LDR ratio. The results of the analysis and discussion showed that in the 2015-2018 period as a whole, the health level of PT. BPR Weleri Makmur is categorized in the healthy category, and the health level progress based on overall credit score at PT. BPR Weleri Makmur in the 2015-2016 period decreased.
\end{abstract}

Keywords: Bank's Health Level, CAMEL Method, Capital, Asset Quality, Management, Earnings, and Liquidity.

*) Mahasiswa Tugas Akhir Prodi Keuangan dan Perbankan Jurusan Akuntansi Politeknik Negeri Semarang

**) Dosen Jurusan Akuntansi Politeknik Negeri Semarang

\section{PENDAHULUAN}

\section{Latar Belakang Masalah}

Dampak krisis awal Juli 1997, terjadi gejolak nilai tukar. Bersamaan dengan itu, pemerintah melakukan pengetatan likuiditas. Kondisi ini memunculkan krisis kepercayaan masyarakat terhadap perbankan nasional, terutama pasca pencabutan ijin usaha 16 bank pada tanggal 1 November 1997. Hal ini berdampak sangat buruk, terutama memicu terjadinya depresiasi kepercayaan terhadap perbankan. (Safri, 2018)

Perbankan mempunyai peranan yang sangatlah besar dalam memajukan perekonomian suatu negara. Hampir semua sektor yang berhubungan dengan keuangan selalu membutuhkan jasa bank. Begitu pentingnya dunia perbankan, sehingga ada anggapan bahwa bank merupakan "nyawa" untuk menggerakkan roda perekonomian suatu negara. Anggapan ini tentu tidak salah, karena fungsi bank sebagai lembaga keuangan sangatlah vital, misalnya dalam hal penciptaan uang, mengedarkan uang, menyediakan uang untuk menunjang kegiatan usaha, 
tempat mengamankan uang, tempat melakukan investasi dan jasa keuangan lainnya. (Kasmir, 2002:2)

Industri perbankan kini telah mengalami perubahan besar dalam beberapa tahun terakhir. Kemajuan usaha suatu bank sangat bergantung dari kepercayaan masyarakat terhadap bank tersebut. Seperti yang disebutkan oleh Budisantoso dan Nuritomo (2013:9), salah satu fungsi bank adalah sebagai agent of trust. Dasar utama kegiatan perbankan adalah kepercayaan (trust), baik dalam hal menghimpun dana maupun penyaluran dana. Masyarakat akan mau menitipkan dananya di bank apabila dilandasi adanya unsur kepercayaan. Masyarakat percaya bahwa uangnya tidak akan disalahgunakan oleh bank, uangnya akan dikelola dengan baik, bank tidak akan bangkrut, dan pada saat yang telah dijanjikan simpanan tersebut dapat ditarik kembali dari bank. Pihak bank sendiri akan mau menyalurkan dananya pada debitur atau masyarakat apabila dilandasi unsur kepercayaan. Pihak bank percaya bahwa debitur tidak akan menyalahgunakan pinjamannya, debitur akan mengelola dana pinjaman dengan baik, debitur akan mempunyai kemampuan untuk membayar pada saat jatuh tempo, dan debitur mempunyai niat untuk mengembalikan pinjaman beserta kewajiban lainnya pada saat jatuh tempo.

Demi menjaga kepercayaan masyarakat atau nasabah maka bank perlu menjaga tingkat kesehatannya. Kesehatan merupakan hal yang paling penting di dalam berbagai bidang kehidupan, baik bagi manusia maupun perusahaan. Kondisi yang sehat akan meningkatkan gairah kerja dan kemampuan kerja serta kemampuan lainnya. Sama seperti halnya manusia yang harus selalu menjaga kesehatannya, perbankan juga harus selalu dinilai kesehatannya agar tetap prima dalam melayani para nasabahnya. Bank yang tidak sehat, bukan hanya membahayakan dirinya sendiri, akan tetapi pihak lain. Penilaian kesehatan bank amat penting disebabkan karena bank mengelola dana masyarakat yang dipercayakan kepada bank. (Kasmir, 2002:41)

Keberadaan Bank Perkreditan Rakyat (BPR) adalah untuk memenuhi kebutuhan masyarakat dalam bidang keuangan dengan ketentuan-ketentuan yang lebih mudah dibandingkan dengan bank umum. Direktur Grup Kepatuhan LPS, Arinto Wicaksono (Antaranews Kepri) mengungkapkan sampai dengan semester pertama di tahun 2018 tercatat sebanyak 89 bank telah dilikuidasi, 83 diantaranya merupakan Bank Perkreditan Rakyat (BPR), 5 merupakan BPR Syariah dan satu bank umum. Oleh karena itu, BPR harus memperhatikan tingkat kesehatannya, sebagaimana diatur dalam Peraturan Bank Indonesia No.9/17/PBI/2007 tentang Sistem Penilaian Tingkat Kesehatan Bank Perkreditan Rakyat (BPR). Sedangkan untuk tata cara penilaian tingkat kesehatan BPR diatur dalam Surat Keputusan Direksi Bank 
Indonesia No. 30/12/KEP/DIR, dimana kedua peraturan ini berlaku di seluruh BPR di Indonesia.

PT. BPR Weleri Makmur adalah sebuah lembaga keuangan bank yang telah berpengalaman lebih dari 25 tahun, dan senantiasa berkembang dengan total asset diatas 350 Milyar Rupiah. Keamanan nasabah adalah prioritas utama PT. BPR Weleri Makmur. Salah satunya adalah dengan menjadi anggota Lembaga Penjamin Simpanan (LPS), sehingga dapat memberi keterangan bagi nasabah karena simpanan dijamin oleh pemerintah.

Berikut merupakan tabel yang berisi beberapa rasio dari PT. BPR Weleri Makmur yang berada di kota Semarang periode 2015-2018:

Tabel 1 Rasio Keuangan PT. BPR Weleri Makmur

\begin{tabular}{|c|c|c|c|c|}
\hline \multirow{2}{*}{ Rasio } & \multicolumn{4}{|c|}{ Tahun } \\
\cline { 2 - 5 } & 2015 & 2016 & 2017 & 2018 \\
\hline CAR & $16,50 \%$ & $18,88 \%$ & $17,72 \%$ & $19,29 \%$ \\
\hline KAP & $1,39 \%$ & $3,62 \%$ & $4,74 \%$ & $2,48 \%$ \\
\hline PPAP & $123,08 \%$ & $111,60 \%$ & $100,00 \%$ & $100,10 \%$ \\
\hline BOPO & $67,95 \%$ & $71,93 \%$ & $65,82 \%$ & $61,67 \%$ \\
\hline LDR & $65,43 \%$ & $71,81 \%$ & $76,70 \%$ & $77,72 \%$ \\
\hline
\end{tabular}

Sumber : Data yang diolah

Berdasarkan tabel diatas menunjukkan kinerja rasio CAR, KAP, PPAP, BOPO, dan LDR pada PT. BPR Weleri Makmur Semarang periode 2015-2018, sedangkan berikut merupakan perkembangan rasio :

Tabel 2 Perkembangan Rasio Keuangan PT. BPR Weleri Makmur

\begin{tabular}{|c|c|c|c|l|}
\hline \multirow{2}{*}{ Rasio } & \multicolumn{3}{|c|}{ Periode } & \multirow{2}{*}{ Keterangan } \\
\cline { 2 - 4 } & $2015-2016$ & $2016-2017$ & $2017-2018$ & \\
\hline CAR & $14,44 \%$ & $-6,13 \%$ & $8,85 \%$ & Fluktuasi \\
\hline KAP & $160,65 \%$ & $30,89 \%$ & $-47,84 \%$ & Turun \\
\hline PPAP & $-9,33 \%$ & $-10,39 \%$ & $0,10 \%$ & Fluktuasi \\
\hline BOPO & $5,86 \%$ & $-8,50 \%$ & $-6,31 \%$ & Fluktuasi \\
\hline LDR & $9,76 \%$ & $6,81 \%$ & $1,32 \%$ & Turun \\
\hline
\end{tabular}

Sumber: Data yang diolah 
Pada tabel diatas dapat terlihat perkembangan rasio CAR, KAP, ROA dan LDR dari PT. BPR Weleri Makmur periode 2015 sampai dengan 2018. Untuk rasio CAR, PPAP, dan BOPO mengalami fluktuasi, sedangkan rasio LDR dan rasio KAP mengalami mengalami penurunan perkembangan. Bisa saja hal tersebut mempengaruhi tingkat kesehatan PT. BPR Weleri Makmur pada periode 2015 hingga 2018.

Penelitian ini bertujuan untuk mengukur rasio keuangan CAMEL dan tingkat kesehatan BPR, BPR yang diteliti yaitu PT. BPR Weleri Makmur yang berada di kota Semarang yang berkantor pusat di Jalan Majapahit, Ruko Gayamsari No.7 Semarang. Hasil penelitian ini akan menggambarkan nilai rasio CAMEL dan tingkat kesehatan BPR tersebut, sehingga dapat diketahui tingkat kesehatan dan perkembangan kesehatan PT. BPR Weleri Makmur periode 2015-2018.

\section{Rumusan Masalah dan Tujuan Penelitian}

Berdasarkan latar belakang yang telah diuraikan diatas maka rumusan masalah yang akan diuji lebih lanjut dalam penelitian ini adalah bagaimana tingkat kesehatan PT. BPR Weleri Makmur tahun 2015 sampai tahun 2018 jika dihitung menggunakan metode CAMEL dan bagaimana perkembangan tingkat kesehatan PT. BPR Weleri Makmur tahun 2015 sampai dengan tahun 2018 ?

Sedangkan, tujuan dari penelitian adalah untuk menganalisis tingkat kesehatan PT. BPR Weleri Makmur periode 2015-2018 jika dihitung menggunakan metode CAMEL dan menganalisis perkembangan tingkat kesehatan PT. BPR Weleri Makmur periode 2015-2018.

\section{LANDASAN TEORI}

\section{Bank}

Berdasarkan Undang-Undang Nomor 10 Tahun 1998 yang dimaksud dengan bank adalah badan usaha yang menghimpun dana dari masyarakat dalam bentuk simpanan dan menyalurkannya ke masyarakat dalam bentuk kredit dan/atau bentuk-bentuk lainnya dalam rangka meningkatkan taraf hidup rakyat banyak. Secara sederhana menurut Kasmir (2002:23), bank diartikan sebagai lembaga keuangan yang kegiatan usahanya adalah menghimpun dana dari masyarakat dan menyalurkannya kembali dana tersebut ke masyarakat serta memberikan jasa-jasa bank lainnya.

\section{Bank Perkreditan Rakyat}

Menurut Undang-Undang Nomor 10 Tahun 1998 Pasal 1 ayat 4, yang dimaksud Bank Perkreditan Rakyat (BPR) adalah bank yang melaksanakan kegiatan usaha secara konvensional 
atau berdasarkan Prinsip Syariah yang dalam kegiatannya tidak memberikan jasa dalam lalu lintas pembayaran.

\section{Laporan Keuangan}

Menurut Myer (dalam Munawir, 2010:5), yang dimaksud dengan laporan keuangan adalah dua daftar yang disusun oleh Akuntan pada akhir periode untuk suatu perusahaan. Kedua daftar itu adalah daftar neraca atau daftar posisi keuangan dan daftar pendapatan atau daftar rugi-laba. Pada waktu akhir-akhir ini sudah menjadi kebiasaan bagi perseroan-perseroan untuk menambahkan daftar ketiga yaitu daftar surplus atau daftar laba yang tak dibagikan (laba yang ditahan).

Dalam Prinsip-Prinsip Akuntansi Indonesia (Ikatan Akuntan Indonesia, Jakarta 1974) dikatakan bahwa laporan keuangan ialah neraca dan perhitungan rugi laba serta segala keterangan-keterangan yang dimuat dalam lampiran-lampirannya antara lain laporan sumber dan penggunaan dana-dana. (Munawir, 2010:6)

Sedangkan menurut Kasmir (2012:280), laporan keuangan bank adalah laporan yang menunjukkan kondisi keuangan bank secara keseluruhan. Dari laporan ini akan terbaca bagaimana kondisi bank yang sesungguhnya, termasuk kelemahan dan kekuatan yang dimiliki. Laporan ini juga menunjukkan kinerja manajemen bank selama satu periode. Dalam laporan keuangan termuat informasi mengenai jumlah kekayaan (assets) dan jenis-jenis kekayaan yang dimiliki (di sisi aktiva); kewajiban jangka panjang maupun kewajiban jangka pendek yang dimilikinya; hasil usaha yang diperoleh bank; serta arus kas suatu bank.

\section{Kesehatan Bank}

Menurut Budisantoso dan Nuritomo (2013:73) Kesehatan bank diartikan kemampuan suatu bank untuk melakukan kegiatan operasional perbankan secara normal dan mampu memenuhi semua kewajibannya dengan baik dan sesuai dengan peraturan perbankan yang berlaku. Berdasarkan Surat Keputusan Direksi Bank Indonesia 30/12/KEP/DIR tanggal 30 April 1997 dikatakan bahwa kesehatan suatu bank merupakan kepentingan semua pihak yang terkait, baik pemilik dan pengelola bank, masyarakat pengguna jasa bank. Penilaian tingkat kesehatan dilakukan dengan penilaian terhadap faktor-faktor Permodalan (Capital), Kualitas Aktiva Produktif (Assets Quality), Manajemen (Management), Rentabilitas (Earning) dan Likuiditas (Liquidity). 
Tabel 4 Penilaian Tingkat Kesehatan Bank

\begin{tabular}{|l|l|l|}
\hline Faktor & Rasio/Komponen yang Dinilai & Bobot \\
\hline \multirow{2}{*}{ Capital } & Rasio Modal terhadap ATMR & $30 \%$ \\
\hline \multirow{3}{*}{ Manset Quality } & a. Rasio APYD terhadap Aktiva Produktif & $25 \%$ \\
\cline { 2 - 3 } & b. Rasio PPAPYD terhadap PPAPWD & $5 \%$ \\
\hline \multirow{2}{*}{ Earning } & 1. Manajemen Umum & $10 \%$ \\
\cline { 2 - 3 } & 2. Manajemen Risiko & $10 \%$ \\
\cline { 2 - 3 } Liquidity & b. Rasio Laba Terhadap Total Asset & $5 \%$ \\
\cline { 2 - 3 } & a. Rasio Alat Likuid terhadap Hutang Lancar & $5 \%$ \\
\cline { 2 - 3 } & b. Rasio Kredit terdapat Dana yang Diterima & $5 \%$ \\
\hline
\end{tabular}

Sumber : SK Direksi BI No. 30/12/KEP/DIR tanggal 30 April 1997

\section{METODE}

\section{Desain Penelitian}

Penelitian ini menggunakan pendekatan kuantitatif untuk menganalisis rasio-rasio yang diukur. Metode kuantitatif sebagai metode ilmiah karena telah memenuhi kaidah-kaidah ilmiah yang konkret, obyektif, terukur, rasional dan sistematis. Menurut Kuncoro (2007:8) metode kuantitatif adalah pendekatan ilmiah terhadap pengambilan keputusan manajerial dan ekonomi. Pendekata ini berangkat dari data.

Penelitian ini bertujuan untuk mengetahui tingkat kesehatan bank dan perkembangan tingkat kesehatan bank pada PT. BPR Weleri Makmur. Data yang digunakan adalah laporan keuangan.

\section{Jenis Data}

Jenis data yang digunakan dalam penelitian ini yaitu data sekunder. Menurut Santoso (2004:59) yang dimaksud data sekunder adalah data yang diperoleh dalam bentuk yang sudah jadi, sudah dikumpulkan dan diolah oleh pihak lain, biasanya sudah dalam bentuk publikasi. Data ini berupa laporan keuangan PT. BPR Weleri Makmur Semarang periode 2015-2018 dan buku-buku referensi.

\section{Metode Pengumpulan Data}

Dalam pengumpulan data sebagai bahan penulisan tugas akhir ini, metode pengumpulan data yang digunakan adalah: 
1. Studi Dokumenter

Data dikumpulkan dari hasil studi sebelumnya yang didokumentasikan dalam bentuk buku. Data yang diperoleh dalam teknik ini adalah data sekunder berupa laporan keuangan yang terdiri dari neraca, laporan laba rugi dan laporan kualitas aktiva produktif.

2. Studi Pustaka

Merupakan metode pengumpulan data melalui kepustakaan dalam rangka mendapatkan teori yang mendukung serangkaian penelitian yang dilakukan penulis. Metode ini dilakukan dengan cara membaca buku maupun literatur serta penelitian terdahulu yang memiliki kaitan dengan penulisan penelitian.

\section{Metode Analisis Data}

Metode yang digunakan dalam penelitian ini adalah dengan menggunakan metode CAMEL (Capital, Asset Quality, Management, Earning, and Liquidity) berdasarkan Surat Keputusan Direktur Bank Indonesia Nomor 30/12/KEP/DIR tanggal 30 April 1997 tentang Tatacara Penilaian Tingkat Kesehatan Bank Perkreditan Rakyat. Penilaian tersebut terdiri dari beberapa faktor, yaitu faktor Permodalan (Capital), Kualitas Aktiva Produktif (Assets Quality), Manajemen (Management), Rentabilitas (Earning) dan Likuiditas (Liquidity). Kemudian untuk menganalisis perkembangan tingkat kesehatan bank, peneliti menggunakan metode Rata-Rata Bergerak (Moving Average).

1. Permodalan (Capital)

Sedangkan untuk menghitung KPMM arau CAR digunakan rumus sebagai berikut :

$\mathrm{CAR}=\frac{\text { Modal }}{A T M R} \times \mathbf{1 0 0 \%}$

Berikut rumus untuk menghitung nilai kredit KPMM atau CAR :

$$
\text { NK CAR }=\mathbf{8 1}+\left(\frac{\text { Rasio } C A R-8 \%}{0,1 \%}\right)
$$

Karena faktor permodalan ini memiliki bobot sebesar 30\% maka untuk mencari Nilai Akhir CAR digunakan rumus sebagai berikut :

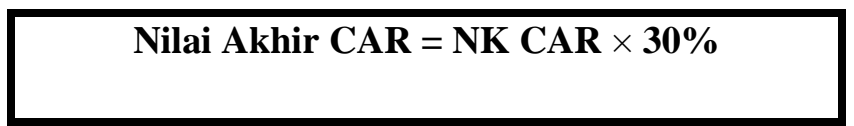

2. Kualitas Aktiva Produktif (Asset Quality)

Berdasarkan Surat Keputusan Direktur Bank Indonesia No. 30/12/KEP/DIR tanggal 30 April 1997 Pasal 8, penilaian terhadap faktor Kualitas Aktiva Produktif (KAP) didasarkan pada 2 rasio yaitu : 
a. Rasio Aktiva Produktif yang Diklasifikasikan terhadap Aktiva Produktif. Apabila Rasio Aktiva Produktif yang Diklasifikasikan terhadap Aktiva Produktif. Untuk menghitung Rasio Aktiva Produktif Yang Diklasifikasikan terhadap Aktiva Produktif digunakan rasio sebagai berikut :

$$
\mathbf{K A P}=\frac{A P Y D}{\text { Aktiva Produktif }} \times \mathbf{1 0 0 \%}
$$

Berikut rumus untuk menghitung nilai kredit rasio KAP :

$$
\text { NK KAP }=\frac{22,5 \%-\text { Rasio } K A P}{0,15 \%}
$$

Karena faktor permodalan ini memiliki bobot sebesar $25 \%$ maka untuk menghitung Nilai Akhir KAP digunakan rumus sebagai berikut :

$$
\text { Nilai Akhir KAP }=\text { NK KAP } \times 25 \%
$$

b. Rasio Penyisihan Penghapusan Aktiva Produktif yang Dibentuk oleh bank terhadap Penyisihan Penghapusan Aktiva Produktif yang Wajib Dibentuk oleh bank atau disingkat rasio PPAP. Untuk menghitung Rasio PPAP digunakan rumus sebagai berikut :

$$
\mathbf{P P A P}=\frac{P P A P \text { yang dibentuk bank }}{P P A P \text { yang } \text { wajib dibentuk }} \times \mathbf{1 0 0 \%}
$$

Berikut rumus untuk menghitung nilai kredit rasio PPAP :

\section{NK PPAP $=$ Rasio PPAP $\times 100$}

Karena faktor permodalan ini memiliki bobot sebesar 5\% maka untuk menghitung Nilai Akhir PPAP digunakan rumus sebagai berikut :

\section{Nilai Akhir PPAP $=$ NK PPAP $\times 5 \%$}

3. Manajemen (Management)

Berdasarkan Surat Keputusan Direktur Bank Indonesia No. 30/12/KEP/DIR tanggal 30 April 1997 Pasal 9, penilaian terhadap faktor manajemen mencakup 2 (dua) komponen yaitu manajemen umum dan manajemen risiko, dengan menggunakan daftar pertanyaan/pernyataan. Jumlah pertanyaan/pernyataan. ditetapkan sebanyak 25 yang terdiri atas 10 pertanyaan/pernyataan manajemen umum dan 15 pertanyaan/pernyataan manajemen risiko. Dengan skala penilaian untuk setiap pertanyaan/pernyataan ditetapkan antara 0 sampai dengan 4 dengan kriteria : 
a. nilai 0 mencerminkan kondisi yang lemah;

b. nilai 1, 2 dan 3 mencerminkan kondisi antara;

c. nilai 4 mencerminkan kondisi yang baik.

4. Rentabilitas (Earning)

Berdasarkan Surat Keputusan Direktur Bank Indonesia No. 30/12/KEP/DIR tanggal 30 April 1997 Pasal 10, penilaian terhadap faktor rentabilitas didasarkan pada 2 (dua) rasio yaitu :

a. Rasio Laba Sebelum Pajak dalam 12 bulan terakhir terhadap Rata-rata Volume Usaha dalam periode yang sama. Rasio ini biasa disebut Return On Asset (ROA). Untuk menghitung rasio ini rumus yang digunakan adalah sebagai berikut:

$$
\mathbf{R O A}=\frac{\text { Laba Sebelum Pajak dalam } 12 \text { bulan terakhir }}{\text { Rata }- \text { Rata Volume Usaha dalam periode yang sama }} \times \mathbf{1 0 0 \%}
$$

Berikut rumus untuk menghitung nilai kredit rasio ROA (Return On Asset):

$$
\text { NK ROA }=\frac{\text { Rasio } R O A}{0,015 \%}
$$

Untuk menghitung nilai akhir dari rasio ini yaitu dengan rumus berikut:

$$
\text { Nilai Akhir ROA = NK ROA } \times 5 \%
$$

b. Rasio Biaya Operasional dalam 12 bulan terakhir terhadap Pendapatan Operasional dalam periode yang sama. Rasio ini biasa disingkat BOPO. Untuk menghitung rasio ini rumus yang digunakan adalah sebagai berikut:

$$
\text { BOPO }=\frac{\text { Biaya Operasional }}{\text { Pendapatan Operasional }} \times \mathbf{1 0 0 \%}
$$

Berikut rumus untuk menghitung nilai kredit rasio Biaya Operasional terhadap Pendapatan Operasional (BOPO):

$$
\text { NK BOPO }=\frac{(100-\text { Rasio } B O P O)}{0,08 \%}
$$

Untuk menghitung nilai akhir dari rasio ini yaitu dengan rumus berikut:

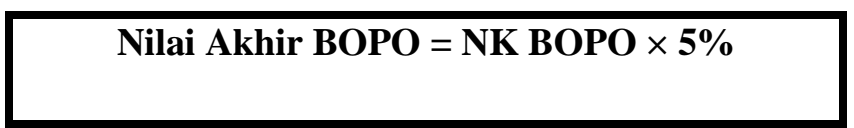

5. Likuiditas (Liquidity)

Berdasarkan Surat Keputusan Direktur Bank Indonesia No. 30/12/KEP/DIR tanggal 30 April 1997 Pasal 11, penilaian terhadap faktor likuiditas didasarkan pada 2 (dua) rasio yaitu : 
a. Rasio Alat Likuid terhadap Hutang Lancar disebut juga Cash Ratio. Dengan rumus sebagai berikut:

$$
\text { Cash Ratio }=\frac{\text { Alat Likuid }}{\text { Hutang Lancar }} \times \mathbf{1 0 0 \%}
$$

Berikut rumus untuk menghitung nilai kredit Cash Ratio:

$$
\text { NK Cash Ratio }=\frac{\text { Cash } \text { Ratio }}{0,05 \%}
$$

Untuk menghitung nilai akhir dari rasio ini yaitu dengan rumus berikut:

$$
\text { Nilai Akhir Cash Ratio = NK Cash Ratio } \times 5 \%
$$

b. Rasio Kredit terhadap Dana yang Diterima oleh Bank atau disebut Loan to Deposit Ratio (LDR). Dengan rumus sebagai berikut:

$$
\mathbf{L D R}=\frac{\text { Kredit }}{\text { Dana yang diterima oleh Bank }} \times \mathbf{1 0 0 \%}
$$

Berikut rumus untuk menghitung nilai kredit LDR:

$$
\text { NK LDR = (115\% - Rasio LDR }) \times 4
$$

Untuk menghitung nilai akhir dari rasio ini yaitu dengan rumus berikut:

$$
\text { Nilai Akhir LDR = NK LDR } \times \mathbf{5 \%}
$$

\section{PEMBAHASAN}

Analisis Penilaian Tingkat Kesehatan PT BPR Weleri Makmur pada Periode 2015-2018

1. Analisis Faktor Permodalan (Capital)

Penilaian tingkat kesehatan PT BPR Weleri Makmur berdasarkan faktor permodalan dihitung dengan menggunakan Capital Adequacy Ratio (CAR), dengan hasil sebagai berikut :

Tabel 5 Faktor Permodalan

\begin{tabular}{|c|r|r|r|c|c|}
\hline Tahun & $\begin{array}{c}\text { Modal } \\
\text { (Ribuan Rp) }\end{array}$ & $\begin{array}{c}\text { ATMR } \\
\text { (Ribuan Rp) }\end{array}$ & CAR & Nilai Kredit & Predikat \\
\hline 2015 & 43.180 .430 & 261.756 .898 & $16,50 \%$ & 165,96 & Sehat \\
\hline 2016 & 50.062 .230 & 265.183 .568 & $18,88 \%$ & 189,78 & Sehat \\
\hline 2017 & 56.661 .568 & 319.736 .728 & $17,72 \%$ & 178,21 & Sehat \\
\hline 2018 & 65.770 .575 & 340.958 .519 & $19,29 \%$ & 193,90 & Sehat \\
\hline
\end{tabular}


Sumber : Data yang diolah

Berdasarkan ketentuan SK Dir. BI Nomor 30/12/KEP/DIR tanggal 30 April 1997, bank-bank diwajibkan untuk memelihara Kewajiban Penyediaan Modal Minimum (KPMM) atau Capital Adequacy Ratio (CAR) sekurang-kurangnya 8\%. Berdasarkan rasio permodalan PT BPR Weleri Makmur pada periode 2015-2018 dapat dikategorikan dalam kategori Sehat, karena diatas ketentuan yang berlaku yaitu 8\%. Semakin besar rasio permodalan yang dimiliki oleh bank, maka akan semakin baik. Hal ini dikarenakan bank mampu menyediakan modal dalam jumlah yang besar. Seiring pertumbuhan modal yang baik, maka kemungkinan risiko yang akan dihadapi juga tinggi.

2. Analisis Faktor Kualitas Aktiva Produktif (Asset Quality)

a. Rasio Aktiva Produktif Yang Diklasifikasikan (APYD) terhadap Aktiva Produktif. Penilaian tingkat kesehatan PT BPR Weleri Makmur berdasarkan faktor kualitas aktiva produktif yang dihitung dengan menggunakan rasio Aktiva Produktif Yang Diklasifikasikan (APYD) terhadap Aktiva Produktif, dengan hasil sebagai berikut:

Tabel 6 Faktor Kualitas Aktiva Produktif dengan Rasio APYD terhadap Aktiva Produktif

\begin{tabular}{|c|r|r|r|r|c|}
\hline Tahun & $\begin{array}{c}\text { APYD } \\
\text { (Ribuan Rp) }\end{array}$ & $\begin{array}{c}\text { Aktiva } \\
\text { Produktif } \\
\text { (Ribuan Rp) }\end{array}$ & KAP & $\begin{array}{c}\text { Nilai } \\
\text { Kredit }\end{array}$ & Predikat \\
\hline 2015 & 4.758 .369 & 342.143 .894 & $1,4 \%$ & 140,73 & Sehat \\
\hline 2016 & 11.308 .316 & 311.958 .081 & $3,6 \%$ & 125,83 & Sehat \\
\hline 2017 & 14.801 .778 & 364.753 .941 & $4,7 \%$ & 118,37 & Sehat \\
\hline 2018 & 9.028 .081 & 390.290 .287 & $2,5 \%$ & 133,50 & Sehat \\
\hline
\end{tabular}

Sumber : Data yang diolah

Menurut Herli (2013:136), rasio KAP dapat dikatakan sehat apabila sama atau kurang dari 10,35\%. Berdasarkan ketentuan SK Dir. BI Nomor 30/12/KEP/DIR tanggal 30 April 1997, rasio APYD terhadap Aktiva Produktif atau Kualitas Aktiva Produktif (KAP) dapat dikatakan sehat apabila dikatakan sehat apabila bernilai kredit lebih dari 80. Sehingga dapat disimpulkan bahwa PT BPR Weleri Makmur tahun 2015-2018 dapat dikategorikan dalam kategori Sehat, karena berada dibawah ketentuan yang berlaku yaitu 10,35\% dan bernilai kredit lebih dari 80. Hal ini dapat diartikan bahwa kecilnya rasio KAP yang diperoleh PT BPR Weleri Makmur menunjukkan, bahwa BPR memiliki aktiva produktif 
bermasalah yang relatif kecil. Semakin kecil rasio KAP, maka semakin baik karena semakin besar tingkat kemungkinan diterimanya kembali dana yang ditanamkan.

b. Rasio Penyisihan Penghapusan Aktiva Produktif (PPAP) terhadap Penyisihan Penghapusan Aktiva Produktif yang Wajib Dibentuk (PPAPWD). Penilaian tingkat kesehatan PT BPR Weleri Makmur berdasarkan faktor kualitas aktiva produktif yang dihitung dengan menggunakan rasio Penyisihan Penghapusan Aktiva Produktif (PPAP) terhadap Penyisihan Penghapusan Aktiva Produktif yang Wajib Dibentuk (PPAPWD), dengan hasil sebagai berikut :

Tabel 7 Faktor Kualitas Aktiva Produktif dengan Rasio PPAP terhadap PPAPWD

\begin{tabular}{|c|r|r|r|r|c|}
\hline Tahun & $\begin{array}{c}\text { PPAP } \\
\text { (Ribuan Rp) }\end{array}$ & $\begin{array}{c}\text { PPAPWD } \\
\text { (Ribuan Rp) }\end{array}$ & $\begin{array}{c}\text { Rasio } \\
\text { PPAP }\end{array}$ & $\begin{array}{c}\text { Nilai } \\
\text { Kredit }\end{array}$ & Predikat \\
\hline 2015 & 2.974 .004 & 2.416 .318 & $123,08 \%$ & 123,08 & Sehat \\
\hline 2016 & 1.633 .379 & 1.463 .601 & $111,60 \%$ & 111,60 & Sehat \\
\hline 2017 & 2.470 .952 & 2.470 .952 & $100,00 \%$ & 100,00 & Sehat \\
\hline 2018 & 2.665 .180 & 2.662 .517 & $100,10 \%$ & 100,10 & Sehat \\
\hline
\end{tabular}

Sumber : Data yang diolah

Menurut Herli (2013:137), rasio PPAP dapat dikategorikan sehat apabila sama atau lebih dari $81 \%$. Berdasarkan ketentuan SK Dir. BI Nomor 30/12/KEP/DIR tanggal 30 April 1997 rasio Penyisihan Penghapusan Aktiva Produktif (PPAP) terhadap Penyisihan Penghapusan Aktiva Produktif yang Wajib Dibentuk (PPAPWD) dapat dikategorikan sehat apabila memiliki nilai kredit sama atau lebih dari 81. Sehingga PT BPR Weleri Makmur pada Periode 2015-2018 dapat dikategorikan dalam kategori Sehat, karena rasio PPAP lebih dari $81 \%$ dan memiliki nilai kredit sama atau lebih dari 81. Semakin besar nilai PPAP pada suatu perusahaan, maka semakin baik bagi perusahaan. Hal ini dikarenakan aktiva produktif yang harus dicadangkan semakin kecil. Begitu juga sebaliknya menurut Yuliyani (2017:50), apabila nilai PPAP semakin kecil maka semakin tidak baik bagi perusahaan, karena semakin besar pula aktiva produktif yang dicadangkan, sehingga dapat menyebabkan kerugian bagi bank.

3. Analisis Faktor Manajemen (Management)

Penilaian tingkat kesehatan PT BPR Weleri Makmur berdasarkan faktor manajemen dihitung dengan menggunakan penilaian manajemen umum dan manajemen risiko dengan hasil sebagai berikut : 
Tabel 8 Faktor Manajemen

\begin{tabular}{|c|c|c|c|c|c|}
\hline Tahun & $\begin{array}{c}\text { Manajemen } \\
\text { Umum }\end{array}$ & $\begin{array}{c}\text { Manajemen } \\
\text { Risiko }\end{array}$ & Jumlah & $\begin{array}{c}\text { Nilai } \\
\text { Kredit }\end{array}$ & Predikat \\
\hline 2015 & 29 & 51 & 80 & 80 & Cukup Sehat \\
\hline 2016 & 29 & 47 & 76 & 76 & Cukup Sehat \\
\hline 2017 & 30 & 48 & 78 & 78 & Cukup Sehat \\
\hline 2018 & 32 & 50 & 82 & 82 & Sehat \\
\hline
\end{tabular}

Sumber : Data yang diolah

Berdasarkan ketentuan SK Dir. BI Nomor 30/12/KEP/DIR tanggal 30 April 1997, dengan hasil penilaian faktor manajemen pada periode 2015-2017 berturut-turut 80, 76, 78, sehingga pada periode 2015-2017 PT BPR Weleri Makmur dapat dikategorikan dalam kategori Cukup Sehat. Periode 2015-2017, manajemen PT BPR Weleri Makmur dikategorikan dalam kategori cukup sehat dikarenakan nilai yang dihasilkan lebih dari 66 dan kurang dari 81. Pada tahun 2018 PT BPR Weleri Makmur dapat dikategorikan dalam kategori Sehat, hal ini disebabkan karena hasil penilaian faktor manajemen PT BPR Weleri Makmur pada tahun 2018 melebihi 81, dengan jumlah nilai 82.

4. Analisis Faktor Rentabilitas (Earning)

a. Rasio Laba Sebelum Pajak dalam 12 bulan terakhir terhadap Rata - Rata Volume Usaha dalam periode yang sama atau disebut juga Return On Asset (ROA). Penilaian tingkat kesehatan PT BPR Weleri Makmur berdasarkan faktor rentabilitas yang dihitung dengan menggunakan rasio Laba Sebelum Pajak dalam 12 bulan terakhir terhadap Rata - Rata Volume Usaha dalam periode yang sama atau disebut juga Return On Asset (ROA), dengan hasil sebagai berikut :

Tabel 9 Faktor Rentabilitas ROA

\begin{tabular}{|c|r|r|r|r|c|}
\hline Tahun & $\begin{array}{c}\text { Laba Sebelum } \\
\text { Pajak } \\
\text { (Ribuan Rp) }\end{array}$ & $\begin{array}{c}\text { Asset } \\
\text { (Ribuan Rp) }\end{array}$ & $\begin{array}{c}\text { Rasio } \\
\text { ROA }\end{array}$ & $\begin{array}{c}\text { Nilai } \\
\text { Kredit }\end{array}$ & Predikat \\
\hline 2015 & 11.605 .501 & 353.057 .539 & $3,3 \%$ & 219,14 & Sehat \\
\hline 2016 & 9.175 .733 & 338.362 .039 & $2,7 \%$ & 180,79 & Sehat \\
\hline 2017 & 13.465 .785 & 390.622 .648 & $3,4 \%$ & 229,82 & Sehat \\
\hline 2018 & 20.428 .675 & 412.735 .754 & $4,9 \%$ & 329,97 & Sehat \\
\hline
\end{tabular}

Sumber : Data yang diolah 
Menurut Herli (2013:139), rasio ROA dapat dikategorikan sehat apabila sama atau lebih dari 1,215\%. Berdasarkan ketentuan SK DIR. BI Nomor 30/12/KEP/DIR tanggal 30 April 1997, rasio ROA dapat dikategorikan sehat apabila memiliki nilai kredit sama atau lebih dari 81. Berdasarkan hasil rasio ROA PT BPR Weleri Makmur periode 2015-2018, rasio ROA pada periode 2015-2018 dapat dikategorikan dalam kategori Sehat. Hal ini dikarenakan rasio ROA pada PT BPR Weleri Makmur lebih dari ketentuan yaitu 1,215\% dengan perolehan nilai kredit lebih sama atau lebih dari 81.

b. Rasio Biaya Operasional dalam 12 bulan terakhir terhadap Pendapatan Operasional dalam periode yang sama atau disingkat BOPO. Penilaian tingkat kesehatan PT BPR Weleri Makmur berdasarkan faktor rentabilitas yang dihitung dengan menggunakan rasio Biaya Operasional dalam 12 bulan terakhir terhadap Pendapatan Operasional dalam periode yang sama atau disingkat BOPO, dengan hasil sebagai berikut :

Tabel 10 Faktor Rentabilitas BOPO

\begin{tabular}{|c|r|r|r|r|c|}
\hline Tahun & $\begin{array}{c}\text { Biaya } \\
\text { Operasional } \\
\text { (Ribuan Rp) }\end{array}$ & $\begin{array}{c}\text { Pendapatan } \\
\text { Operasional } \\
\text { (Ribuan Rp) }\end{array}$ & $\begin{array}{c}\text { Rasio } \\
\text { BOPO }\end{array}$ & $\begin{array}{c}\text { Nilai } \\
\text { Kredit }\end{array}$ & Predikat \\
\hline 2015 & 24.019 .039 & 35.348 .330 & $67,95 \%$ & 400,63 & Sehat \\
\hline 2016 & 23.207 .954 & 32.263 .449 & $71,93 \%$ & 350,84 & Sehat \\
\hline 2017 & 25.850 .328 & 39.276 .491 & $65,82 \%$ & 427,30 & Sehat \\
\hline 2018 & 32.449 .275 & 52.620 .998 & $61,67 \%$ & 479,17 & Sehat \\
\hline
\end{tabular}

Sumber : Data yang diolah

Menurut Herli (2013:139), rasio BOPO dapat dikategorikan sehat apabila sama atau kurang dari 93,52\%. Berdasarkan ketentuan SK Dir. BI Nomor 30/12/KEP/DIR tanggal 30 April 1997, rasio BOPO dapat dikategorikan sehat apabila memiliki nilai kredit sama atau lebih dari 81. Dapat disimpulkan, bahwa rasio BOPO pada PT BPR Weleri Makmur periode 2015-2018 dapat dikategorikan dalam kategori Sehat, karena jika dilihat dari hasil perhitungan rasio BOPO berada dibawah ketentuan yaitu 93,52\% dengan perolehan nilai kredit diatas 81 . 
5. Analisis Faktor Likuiditas (Liquidity)

a. Rasio Alat Likuid terhadap Hutang Lancar atau disebut juga Cash Ratio. Penilaian tingkat kesehatan PT BPR Weleri Makmur berdasarkan faktor likuiditas yang dihitung dengan menggunakan rasio Alat Likuid terhadap Hutang Lancar atau disebut juga Cash Ratio, dengan hasil sebagai berikut :

Tabel 11 Faktor Likuiditas Cash Ratio

\begin{tabular}{|c|c|c|c|c|c|}
\hline Tahun & $\begin{array}{c}\text { Alat Likuid } \\
\text { (Ribuan Rp) }\end{array}$ & $\begin{array}{c}\text { Hutang } \\
\text { Lancar } \\
\text { (Ribuan Rp) }\end{array}$ & $\begin{array}{c}\text { Cash } \\
\text { Ratio }\end{array}$ & $\begin{array}{c}\text { Nilai } \\
\text { Kredit }\end{array}$ & Predikat \\
\hline 2015 & 114.619 .471 & 299.053 .949 & $38,33 \%$ & 766,55 & Sehat \\
\hline 2016 & 72.146 .127 & 276.177 .145 & $26,12 \%$ & 522,46 & Sehat \\
\hline 2017 & 68.876 .042 & 312.474 .045 & $22,04 \%$ & 440,84 & Sehat \\
\hline 2018 & 75.008 .006 & 334.288 .183 & $22,44 \%$ & 448,76 & Sehat \\
\hline
\end{tabular}

Sumber : Data yang diolah

Menurut Herli (2013:139), Cash Ratio dapat dikategorikan sehat apabila sama atau lebih dari 4,05\%. Berdasarkan ketentuan SK Dir. BI Nomor 30/12/KEP/DIR tanggal 30 April 1997, Cash Ratio dapat dikategorikan sehat apabila memiliki nilai kredit sama atau lebih dari 81. Sehingga dapat disimpulkan, bahwa Cash Ratio PT BPR Weleri Makmur pada periode 2015-2018 dapat dikategorikan dalam kategori Sehat. Dapat dikatakan sehat, karena hasil perhitungan Cash Ratio PT BPR Weleri Makmur lebih dari 4,05\% dan perolehan nilai kredit lebih dari 81.

b. Rasio Kredit terhadap Dana yang Diterima atau disebut juga Loan Deposit Ratio (LDR). Penilaian tingkat kesehatan PT BPR Weleri Makmur berdasarkan faktor likuiditas yang dihitung dengan menggunakan Rasio Kredit terhadap Dana yang Diterima atau disebut juga Loan Deposit Ratio (LDR), dengan hasil sebagai berikut: 
Tabel 12 Faktor Likuiditas Cash Ratio

\begin{tabular}{|c|r|r|r|r|c|}
\hline Tahun & $\begin{array}{c}\text { Kredit } \\
\text { (Ribuan Rp) }\end{array}$ & $\begin{array}{c}\text { Dana yang } \\
\text { Diterima } \\
\text { (Ribuan Rp) }\end{array}$ & LDR & $\begin{array}{c}\text { Nilai } \\
\text { Kredit }\end{array}$ & Predikat \\
\hline 2015 & 228.284 .248 & 348.916 .963 & $65,43 \%$ & 198.29 & Sehat \\
\hline 2016 & 240.498 .189 & 334.900 .502 & $71,81 \%$ & 172.75 & Sehat \\
\hline 2017 & 296.647 .898 & 386.741 .297 & $76,70 \%$ & 153.18 & Sehat \\
\hline 2018 & 316.488 .585 & 407.230 .264 & $77,72 \%$ & 149.13 & Sehat \\
\hline
\end{tabular}

Sumber : Data yang diolah

Menurut Herli (2013:139), rasio LDR dapat dikategorikan sehat apabila sama atau kurang dari 94,75\%. Berdasarkan ketentuan SK DIR. BI Nomor 30/12/KEP/DIR tanggal 30 April 1997, rasio LDR dapat dikategorikan sehat apabila memiliki nilai kredit sama atau lebih dari 81. Sehingga dapat disimpulkan, bahwa Loan Deposit Ratio (LDR) PT BPR Weleri Makmur pada periode 20152018 dapat dikategorikan dalam kategori Sehat, karena jika dilihat dari hasil perhitungan rasio LDR selalu berada dibawah 94,75\% dengan perolehan nilai kredit lebih dari 81.

6. Hasil Penilaian Tingkat Kesehatan PT BPR Weleri Makmur pada Periode 2015-2018

Berdasarkan ketentuan yang diatur dalam SK Dir.BI No.30/12/KEP/DIR tanggal 30 April 1997 pasal 13, penilaian tingkat kesehatan bank ditetapkan dalam 4 (empat) golongan predikat tingkat kesehatan Bank, sebagai berikut:

a. Nilai kredit 81 sampai 100 diberi predikat sehat.

b. Nilai kredit 66 sampai dengan kurang dari 81 diberi predikat Cukup Sehat.

c. Nilai kredit 51 sampai dengan kurang dari 66 diberi predikat Kurang Sehat.

d. Nilai Kredit 0 sampai dengan kurang dari 51 diberi predikat Kurang Sehat.

Berikut merupakan hasil penilaian tingkat kesehatan PT BPR Weleri Makmur pada Periode 2015-2018:

Tabel 13 Hasil Penilaian Kesehatan PT BPR Weleri Makmur

\begin{tabular}{|c|c|c|}
\hline Tahun & Nilai Kredit & Predikat \\
\hline 2015 & 88,00 & Sehat \\
\hline 2016 & 87,60 & Sehat \\
\hline 2017 & 87,80 & Sehat \\
\hline 2018 & 88,20 & Sehat \\
\hline
\end{tabular}

Sumber : Data yang diolah 


\section{PENUTUP}

\section{Kesimpulan}

Penelitian ini bertujuan untuk menilai dan menganalisis tingkat kesehatan PT. BPR Weleri Makmur jika dihitung dengan menggunakan metode CAMEL pada periode 2015-2018 berdasarkan Surat Keputusan Direktur Bank Indonesia No. 30/12/KEP/DIR tanggal 30 April 1997. Berdasarkan hasil analisis dan pembahasan menunjukkan bahwa pada periode 20152018 secara keseluruhan, tingkat kesehatan PT. BPR Weleri Makmur dikategorikan dalam kategori sehat, dan perkembangan tingkat kesehatan berdasarkan nilai kredit pada PT. BPR Weleri Makmur pada periode 2015-2016 mengalami penurunan, sedangkan pada periode 2016-2018 mengalami kenaikan. Hal tersebut berdasarkan hasil perhitungan sebagai berikut :

1. Secara keseluruhan, tingkat kesehatan PT BPR Weleri Makmur pada periode 2015-2018 dapat dikategorikan Sehat, karena dilihat dari nilai kredit keseluruhan yang diperoleh pada periode 2015-2018 lebih dari 81. Hal tersebut berdasarkan hasil perhitungan dari faktor-faktor penilaian kesehatan bank sebagai berikut :

a. Faktor permodalan (Capital) PT BPR Weleri Makmur periode 2015-2018 dapat dikategorikan Sehat, karena rasio CAR telah melampaui 8\% dan nilai kredit lebih dari 81. Nilai akhir maksimum selama periode 2015-2018 yaitu sebesar 100, dengan nilai akhir setelah dikalikan bobot sebesar 30 .

b. Faktor Kualitas Aktiva Produktif (Assets Quality) PT BPR Weleri Makmur periode 2015-2018 dapat dikategorikan Sehat, karena nilai kredit lebih dari 81, dengan rasio KAP kurang dari 10,35\% dan rasio PPAP lebih dari $81 \%$.

c. Faktor Manajemen (Management) PT BPR Weleri Makmur periode 2015-2017 dapat dikategorikan Cukup Sehat, karena nilai kredit yang dihasilkan masuk pada golongan nilai diantara 66 sampai dengan kurang dari 81. Sedangkan pada tahun 2018 faktor manajemen dapat dikategorikan Sehat, karena nilai kredit yang dihasilkan lebih dari 81.

d. Faktor Rentabilitas (Earning) PT BPR Weleri Makmur periode 2015-2018 dapat dikategorikan Sehat, karena nilai kredit yang dihasilkan lebih dari 81 dengan ROA lebih dari 1,215\% dan rasio BOPO kurang dari 93,52\%.

e. Faktor likuiditas (Liquidity) PT BPR Weleri Makmur periode 2015-2018 dapat dikategorikan Sehat, karena nilai kredit yang dihasilkan lebih dari 81 dengan Cash Ratio lebih dari 4,05\% dan rasio LDR kurang dari 94,75\%. 
2. Perkembangan tingkat kesehatan berdasarkan nilai kredit secara keseluruhan, PT. BPR Weleri Makmur pada periode 2015-2016 mengalami penurunan, sedangkan pada periode 2016-2018 mengalami kenaikan.

\section{Keterbatasan Penelitian}

Keterbatasan penelitian ini adalah penilaian metode CAMEL hanya didasarkan pada data-data keuangan perusahaan, untuk faktor manajemen data yang diperoleh hanya berupa nilai manajemen tanpa dilakukan wawancara, dan penelitian ini lebih jauh terkait kebijakan manajemen bank, sehingga untuk beberapa data yang memerlukan penjelasan kualitatif tidak dapat dieksplorasi dalam penelitian ini. Penelitian ini terbatas selama 4 tahun yaitu periode 2015 sampai dengan 2018.

\section{Agenda Penelitian Mendatang}

Berdasarkan keterbatasan penelitian diatas, maka saran yang diusulkan untuk penelitian mendatang yaitu dengan menambah periode penelitian dan melakukan wawancara secara langsung untuk mengetahui penilaian manajemen terkait kebijakan manajemen bank, agar untuk beberapa data yang memerlukan penjelasan kualitatif dapat dieksplorasi.

\section{DAFTAR PUSTAKA}

Asmorowati, Wahyu. 2018. Analisis Tingkat Kesehatan PT BPR Cepu Nasionalbank dengan Metode CAMEL Periode 2013-2017. Tugas Akhir. Semarang: Politeknik Negeri Semarang

Budisantoso, Totok dan Nuritomo. 2013. Bank dan Lembaga Lain. Jakarta: Penerbit Salemba Empat

Herli, Ali Suyanto. 2013. Buku Pintar Pengelolaan BPR \& Lembaga Keuangan Pembiayaan Mikro. Yogyakarta: CV. ANDI OFFSET

Jacob, Jeremiah Kevin Dennis. 2013. Analisis Laporan Keuangan dengan Menggunakan Metode CAMEL Untuk Menilai Tingkat Kesehatan Perbankan. Jurnal Emba. Vol.1 No.3 September 2013 ISSN 2303-1174 Hal. 691-700

Kasmir. 2002. Dasar-Dasar Perbankan. Jakarta: PT. Rajagrafindo Persada Kasmir. 2012. Manajemen Perbankan. Jakarta: PT. Rajagrafindo Persada Kuncoro, Mudrajad. 2007. Metode Kuantitatif: Teori dan Aplikasi Untuk Bisnis Dan Ekonomi. Yogyakarta: UPP STIM YKPN

Munawir. 2010. Analisa Laporan Keuangan. Yogyakarta: Liberty Yogyakarta 
Paputungan, Dwi Febriana. 2016. Penilaian Tingkat Kesehatan Bank Menggunakan Metode CAMEL Pada PT. Bank Rakyat Indonesia Cabang Manado Periode 2010-2015. Jurnal Emba. Vol.4 No.3 September 2016 ISSN 2303-1174 Hal. 729-740

Surat Keputusan Direksi Bank Indonesia No. 30/12/KEP/DIR Tentang tata cara Penilaian Tingkat Kesehatan BPR

Santoso, Singgih dan Fandy Tjiptono. 2004. Riset Pemasaran Konsep dan Aplikasi dengan SPPSS. Jakarta: PT. Elex Media Komputindo

Taswan. 2012. Manajemen Perbankan. Yogyakarta: UPP STIM YKPN Yogyakarta

Undang-Undang Republik Indonesia No. 10 Tahun 1998 Tanggal 10 November 1998 Tentang Perbankan

Yanti, Luh Putuh Ita Purnama, I Wayan Suwendra dan Gede Putu Agus Jana Susila. 2014. Analisis Tingkat Kesehatan Bank dengan Menggunakan Metode CAMEL. e-Journal Bisma Universitas Pendidikan Ganesha. Vol.2

Yuliyani, Intan. 2017. Analisis Penilaian Tingkat Kesehatan Bank Berdasarkan Metode CAMEL (Capital, Asset Quality, Management, Earning, dan Liquidity) Pada PD. BPR BKK Kudus Periode 2013-2018. Tugas Akhir. Semarang: Politeknik Negeri Semarang 